
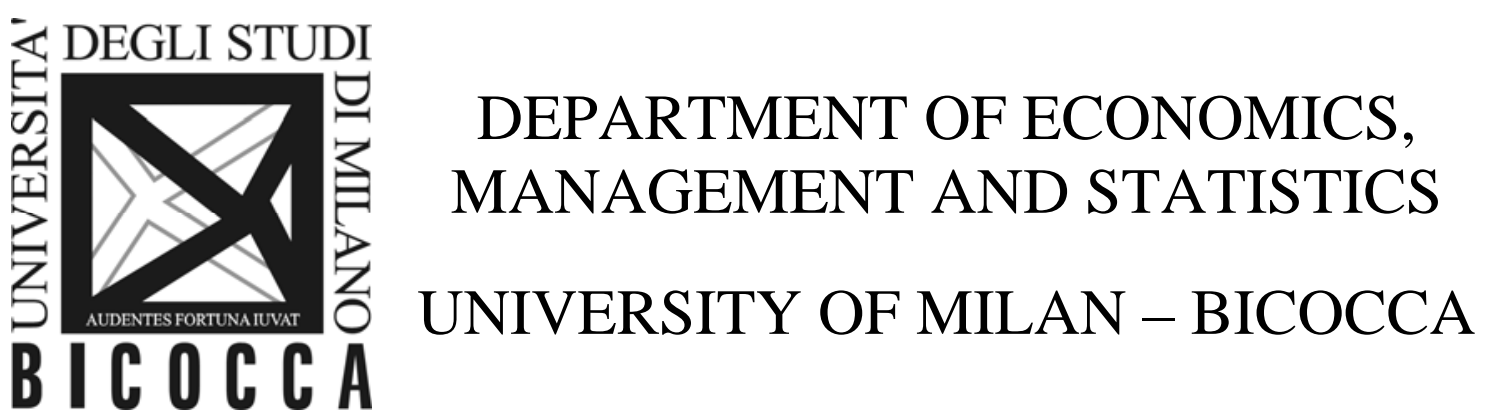

DEMS WORKING PAPER SERIES

\title{
Longevity's factors in small-scale business system: An Italian case study during the 20th century
}

\author{
Ilaria Suffia
}

No. 301 - April 2015

Dipartimento di Economia, Metodi Quantitativi e Strategie di Impresa Università degli Studi di Milano - Bicocca 


\title{
Longevity's factors in small-scale business system: An Italian case study during the $20^{\text {th }}$ century
}

\author{
Ilaria Suffia \\ Department of Economics, Management and Statistics \\ University of Milan-Bicocca*
}

\begin{abstract}
Firms' survival and longevity have recently emerged as a new intriguing theme of business history, spreading from the initial studies on family business to all forms of business. In family business the transition to the next generation can represent a strong limit to survival, as it depends on three different longevity factors: the family members' involvement and commitment, the preparation of an adequate succession planning and the presence of a competitive advantage. Temporal continuity has become an independent topic involving all types of business, with respect to size, ownership and sectorial diversity. The goal of the analysis was to identify the determinants of longevity. The present research moves along this second line of investigation, focusing on small-scale businesses and taking into consideration a case study. The small and medium-scale (SME) system examined is that of Sesto San Giovanni, one of the most important Italian Company-town during the $20^{\text {th }}$ century, considered the 'industrial district' of Milan. The study first verifies the evolution of the local SMEs system, highlighting its development during the century. Having defined the context, the attention shifts to the temporal survival of local businesses and its determinants. Finally, the research includes the history of several enterprise experiences to illustrate the analysis' results.
\end{abstract}

Keywords: Economic History; Micro-Business History: Europe: 1913-

JEL codes: N840

\footnotetext{
*Piazza Ateneo Nuovo 1, 20126 Milan, Italy, e-mail: ilaria.suffia@unimib.it
} 


\section{Introduction}

Business history has recently added to traditional themes ${ }^{1}$ of research the issue of business longevity ${ }^{2}$, which was something that had not previously been examined as an independent subject.

Initial research on this topic focused only on the temporal persistence of family businesses ${ }^{3}$. Their persistence made it necessary to investigate this aspect more deeply. The main need was felt to understand how family businesses managed to cope with the various generational transitions because it was found that the rate of survival of family businesses through successive generations was very low, especially in the third generation ${ }^{4}$. Researchers' attention shifted next at general level. They attempted to define the general characteristics determining the longevity of this type of industry.

\footnotetext{
${ }^{1}$ In general, Business History researches focused on the study of the 'historical evolution of business systems, entrepreneurs, and firms, as well as their interaction with their interaction with their political, economic and social environment'; Geoffrey Jones and Jonathan Zeitlin (edited by), The Oxford Handbook of Business History, Oxford University Press, 2007, p. 7.

The most recognized scholar, from '50s, was Alfred D. Chandler. He creates the paradigm of 'big business'. So for a long time business historians concentrated their efforts in this way.

Nevertheless, the necessity to compare the business history study with others discipline determines the open to new scenario of research. That includes to take in consideration, for example, different firm's form and strategies, new methodologies of research and a new chronological perspectives. For more details on the state of the art of business history research, see Geoffrey Jones and Jonathan Zeitlin (edited by), The Oxford Handbook of Business History, cit.

Instead, for a global view on business history see Franco Amatori and Geoffrey Jones (edited by), Business History around the world, Cambridge, CUP, 2003.

Finally, in general on the business firms see Franco Amatori, Andrea Colli, Business History. Complexities and comparaisons, Routledge, London, 2011.

${ }^{2}$ Examples of recent studies in this field are: A. Bakr Ibrahim, Jean McGuire and K. Soufani, An Empirical Investigation of Factors Contributing to Longevity of Small Family Firms, in Global Economy \& Finance Journal, vol. 2, September 2009; Guido Corbetta and Carlo Salvato, Strategies for Longevity in Family Firms: a European Perspective, Palgrave MacMillan, 2012; Thomas Marcus Zelleweger, Robert S. Nason, Mattias Nordqvist, From longevity to Transgenerational Entrepreneruship of Families. Introducing Family Entrepreneurial Orientation, in Family Business Review, vol. 25, no. 2, June 2012, pp. 136-155; Philippe J. Perricone, John R. Earle, Ian M. Taplin, Patterns of Succession and Continuity in Family-Owned Business. Study of Ethnic Community, Family Business Review, vol. 14, no. 2, 2001, pp. 105-121; Josiane Fahed-Sreih, Salpie Djoundourian, Determinants of Longevity and Success in Lebanese Family Business. An exploratory Study, in Family Business Review, vol. 19, no. 3, 2006, pp. 225-234.

${ }^{3}$ The book edited by Panikkos Zata Poutziouris, Kosmas X. Smyrnios and Sabine B. Klein, Handbook of Research on Family Business, Massachusetts, Edward Elgar Publishing, 2006, covers all the issues linked with family business research. For an example in comparative terms, between Italy and Spain, see Andrea Colli, Esteban Garcia-Canal and Mauro F. Guillén, Family character and international entrepreneurship: a historical comparison of Italian and Spanish 'new multinationals', in Business History Review, vol. 55, no. 1, January 2013, pp. 119-138.

${ }^{4}$ Cfr: A. Bakir Ibrahim, J. McGuire and K. Soufani, An Empirical Investigation, cit., p. 1.
} 
Three key elements were identified to explain the temporal survival of family businesses: the family members' involvement and commitment, the preparation of an adequate plan of succession and the presence of a competitive advantage ${ }^{5}$.

Interest in defining the components of longevity was not limited to family-run businesses alone. On the contrary, as already mentioned, temporal continuity became an independent topic involving all the numerous aspects of business history. Research involved all types of business, with respect to size, ownership and sectorial diversity ${ }^{6}$. Other areas of analysis concerned the relations between longevity and some of the determinants of a business, such as the entrepreneur and the various forms of ownership, innovations, the market and financial relations ${ }^{7}$. The present study investigates the first area of analysis, more specifically the longevity of small and medium enterprises ${ }^{8}$. The research was based on a case study, taking into consideration a specific small and medium-scale business system.

The literature on small and medium enterprises highlights, though only indirectly, certain aspects that may have had a positive influence on their temporal persistence. A number of these aspects are of a general nature. They can be attributed to the overall production system of smaller firms. Others involve the business as an independent entity. The first general element that may have contributed to the longevity of SMEs is the predisposition of the area to the establishment of economic and productive activities. The presence of an "industrial atmosphere" is therefore an indispensable condition for allowing the industrial values rooted in the area to prolong their positive effects over time 9 . The local authorities are another factor that can support the

\footnotetext{
${ }^{5}$ Cfr: ibid., p. 7. For further details of the strategy adopted by SMEs, see G. Corbetta and C. Salvato, Strategies for Longevity, cit.

${ }^{6}$ For details of SMEs, see, for example, the essay by A. Bakir Ibrahim, J. McGuire and K. Soufani, An Empirical Investigation, cit., pp. 1-21.

${ }^{7}$ For further details of business theory see P. A. Toninelli, Storia d'impresa, $2^{\text {nd }}$ edition, Bologna, II Mulino, 2012, pp. 13-56. With regard to entrepreneurship, see J. L. Garcia-Ruiz and P.A. Toninelli (edited by), The Determinants of Entrepreneurship, London, Pickering \& Chatto, 2010.

${ }^{8}$ The acronyms SME and LE are used herein to refer to small and medium enterprise and to large enterprise, respectively.

${ }^{9}$ The concept of "industrial atmosphere" was introduced by A. Marshall. For further details, see G. Becattini (edited by), Economia della produzione, Isedi, Milan, 1975. In the Silicon Valley's case, for example, is described the presence of a knownledge "in the air", conducing at the creation on an ecosystem. In particular, 'Valley's ecosystem is 'a system situated for growing new firms and for learning from each other both through success and failures; Martin Kenney (edited by), Understanding Silicon Valley. The anatomy of a Entrepreneurial Region, Stanford University Press, Stanford, 2010, pp. xiv- xv.

The importance of the environment in which the business system grows also emerges in studies on comparative business systems. The pioneer of these works is Richard Whitley. He defines this concept
} 
maintenance of an industrial inclination of an area, especially at a local level. The active role of public administration - in some specific fields, such as infrastructures, business services and urban land use planning - was a decisive factor in overcoming firms' temporal limits. For instance, the presence of local government plans that are not limited to the construction of new factories undoubtedly has a positive effect on the long-term stability of an enterprise ${ }^{10}$. The environment, in both territorial and local government terms, therefore, appears to be the basic general requirement allowing SMEs to continue.

The other components of business longevity refer to attributes more strictly connected with individual firms. The extreme variability of SMEs ${ }^{11}$ makes it difficult to summarise these aspects clearly. However, as will be shown in the following analysis, two elements can be considered as common persistent factors for the smaller firms. One is specialisation in production, particularly with regard to the specific target market. The other factor is the type of ownership and management, with specific reference to the skills and attitudes of the governing bodies. In this sense, the "will to do", supported by exceptional "ability to do", was behind the success of numerous Italian SMEs ${ }^{12}$.

In short, this research aimed to find answers to three fundamental questions. The first question concerns the characteristics of the industrial system examined: How was the economic and productive system structured and how did it develop? The second issue focus on the longevity of local SMEs. The third objective aims to identify the persistence factors in the world of SMEs.

The economic and productive context taken into consideration in view of answering these questions was Sesto San Giovanni, a city situated approximately 10 kilometres from the North-East of Milan. In the $20^{\text {th }}$ century, this city enjoyed a long period of

analysing the business systems in East Asia; R. Whitley, Business Systems in East Asia, SAGE, London, 1992. For the European case see R. Whitley, European Business System. Firms and Markets in their National contexts, SAGE, London, 1992.

In particular in the literature on business system is highlighted the importance of 'society's institutional, including cultural, set-up [as] determinant of wealth and groth'; Nicolai J. Foss, Understanding Business Systems: an Essay on the Economics and Sociology of Economic Organization, wp 97-6, Department of Industrial Economics and Strategy, Copenhagen Business School, 1997, p. 4.

${ }^{10}$ For more about the role of local institutions in the area of SMEs, see F. Signorini (edited by), Lo sviluppo locale: un'indagine della Banca d'Italia sui distretti industriali, Corigliano Calabro, Mediana Libri, 2000.

${ }^{11}$ A. Colli and M. Rose talk about "intrinsic diversity"; A. Colli and M. Rose, Family Business, in G. Jones and J. Zeitlin (edited by), The Oxford Handbook of Business History, Oxford, Oxford University Press, 2007, p. 194.

${ }^{12}$ See the cases of Prato and Veneto studied in M. Lungonelli, Sulle origini del distretto industriale pratese, in C.M. Belfanti and T. Maccabelli (edited by), Un paradigma per i distretti industriali. Radici storiche, attualità $e$ sfide future, Brescia, Grafo, 1997, and G.L. Fontana, Radici storiche dei sistemi produttivi del Veneto, in ibid. 
intense industrial growth ${ }^{13}$. Sesto San Giovanni began as agricultural village. The city slowly began to changes in the $19^{\text {th }}$ century. Its transformation into an industrial city came rapidly and definitively at the beginning of the following century. In particular, Sesto San Giovanni refined its productive specialization in the major sectors of the second industrial revolution, such as the mechanical and engineering industries, metalworking, electromechanical engineering and electrical engineering ${ }^{14}$.

Several factors have contributed to the industrial development of the city. Positioning is the most important. Sesto San Giovanni is very close to Milan. It is also near Monza. Milano and Monza were two traditional commercial centres that were very important for their market in the period. Moreover, Milan is a historical financial town. At the beginning of the twentieth century, in this city there was a huge ferment in investment in industrial activities. The spatial positioning of Sesto San Giovanni is also favourable in terms of logistics. The city is located at very important transport crossway. It is joined to the major commercial cities of Milan and Monza by urban and railway transport. Above all, it is connected with Europe throughout the San Gottardo' railway.

Finally, another positive aspect for the settlement of industries was the possibility to find local work force that was also cheaper ${ }^{15}$.

These elements allowed the industrial development of Sesto San Giovanni. In only one decade, the city became one most important Italian 'company-towns'. In fact, in the first 10 years of the $20^{\text {th }}$ century some of the main factories in Italy were established. In 1903, Breda arrived. In 1905 Ercole Marelli settled there, and in 1906 the Falck plant was built. After the First World War founded Magneti Marelli was founded ${ }^{16}$. These

\footnotetext{
${ }^{13}$ Sesto San Giovanni is one of the most sensational and specialised industrial achievements. The economic and territorial dynamics of this Lombardy town played a major role in leading to "the sedimentation, in a traditional rural village, of some of the most significant entrepreneurial experiences in Italy [...]". Besides, the sectors involved in this wave of industrialisation were those that used the "more innovative 'heavy' technologies - from steel to electrical engineering", namely the most capital-intensive and largest ones; cfr. V. Varini, L'opera condivisa. La città delle fabbriche. Sesto San Giovanni 1903-1952. L'industria, Milan, Franco Angeli, 2006, p. 7.

${ }^{14}$ Here one important note for this study. In fact, it is important to clarify that in this research are considered only these particular sectors. This choice depends on the particular industrial vocation observed - as highlighted - in Sesto San Giovanni.

${ }^{15}$ For more details see Claudio Pavese, I caratteri originali dell'insediamento, cit., pp. 129-134.

${ }^{16}$ The history of big business in Sesto San Giovanni is in V. Varini, L'opera condivisa. La città delle fabbriche. Sesto San Giovanni 1903-1952. L'industria, Milano, Franco Angeli, 2006; V. Varini, La metamorfosi industriale: dalla città delle fabbriche all'impresa diffusa, in L. Trezzi, Sesto San Giovanni. 1953-1973. Economia e società: equilibrio e mutamento, Milano, Skira, 2007. Other informations about industries in Sesto San Giovanni are in L. Berti, C. Donegà, Sesto San Giovanni. Gli scenari del cambiamento, Milano, Franco Angeli, 1992.
} 
large enterprises established an increasing - as observed later in the paper - number of small and medium-sized local industries.

The initial part of the study highlights, via an overview of the extensive literature produced on the subject, the essential features of the local production scenario in the period considered (chapters 1 and 2). The next part focuses on the longevity of SMEs and presents a reconstruction and temporal analysis of the overall picture of small-scale businesses in Sesto (chapters 3 and 4). The sources used were mainly private and official periodicals ${ }^{17}$ that listed the names of the local production activities. These periodicals were mainly town guides and local industrial directories. The publication that provided the most information was the Guida Savallo, covering Milan and its province ${ }^{18}$. Other official documents, such as lists from the 1939 Industrial and Commercial Census, the 1948 publication by the Upper Italy Sub-Committee and the 1975 Town Development Plan ${ }^{19}$, were also used to complement and verify the data in the Savallo Guide and other periodicals. The last part of the study addresses the factors determining the longevity of SMEs (chapters 5 and 6). Most of the information was retrieved from official files of individual businesses held at the Milan Chamber of Commerce. Each file includes a different number of documents chronicling the life of the

\footnotetext{
${ }^{17}$ By periodical sources in general is meant all materials that allowed a temporal reconstruction of the production units present in the Sesto San Giovanni area through time. The following guides and directories are highlighted in particular: Guida Savallo di Milano e provincia, Guida Industriale di Milano e Provincia, Milan, 1910 (abbreviated to GMI 10); Guida di Sesto San Giovanni Balsamo e Cinisello, Sesto San Giovanni, 1927; Guida Ufficiale della Città di Sesto San Giovanni, Milan, 1936; Guida alle industrie della provincia di Milano, Milan, 1973 (abbreviated to GMI 73); Api Milan: guida dell'associazione piccole e medie industrie di Milan e provincia, issues 1982-83 to 1986-1987 (bulletins abbreviated to API).

${ }^{18}$ It should be noted that this type of source is not generally used for this purpose. However, a lack of material on SMEs has made them indispensable in this work reconstructing name by name of local production firms. Overall, the publication taken into most consideration, in terms of continuity and availability, was the Savallo Guide to Milan and its province. Each volume of the Savallo Guide contains a section listing the names of the businesses operating in Sesto San Giovanni, grouped by activity. This allowed the retrieval of some information on the reference sector for each production unit.

To know more about the Savallo Guide, log on to www.lombardiabeniculturali.it/pereco/schede/551.

Volumes of the Savallo Guide published from 1915 to 1971 were taken into consideration, namely those readily available and able to provide useful information for the research. Issues prior to 1915 were not available. Issues after 1971 could not be used due to a change in the structural organisation of the content. The list of firms is no longer divided according to location, so the material did not meet the requirement of territorial limitation.

For further details, see I. Suffia, Un secolo di piccola e media impresa, cit., pp. 81-82.

${ }^{19}$ 1937-39 Industrial and Commercial Census, Milan Chamber of Commerce Archives, box no. 2093, file no. 1/b/231; 1975 Town Development Plan, Sesto San Giovanni town archives, PRG cupboard. For further information on the Upper Italy Subcommitee Industry, refer to G. Maione, Tecnocrati e mercanti. L'industria italiana tra dirigismo e concorrenza internazionale (1945-1950), Milan, 1986.
} 
enterprise. The information concerns the fulfilment of the statutory requirement. In particular, these legal obligations concerned the declaration of the start and end of activities, variations in personnel data of the firm such as name and address, changes in the legal form of the enterprise and changes in the ownership or management. Thus, with a treatment of the source it was possible to draw out data on the history of the enterprise. These data provide information regarding both the longevity of the firm and the features of this longevity ${ }^{20}$.

\section{Industry in Sesto San Giovanni - a century-long journey}

The evolution of the industrial system in Sesto followed the general growth of the process of modernisation in Italy. Up until the 1980s, Italy's economic growth can be divided into three main stages. The first period, from the Unification in 1861 to the First World War, is that in which the cornerstones of modernisation were laid. In the second period, between the two world wars, the foundations laid previously were strengthened. The third stage is characterised by intense expansion, especially between 1951 and $1973^{21}$. The trend in Italy' gross domestic product (GDP) (Table 1) shows the progress in the country's industrial revolution. Similarly, as we will see, the production industry in Sesto San Giovanni developed over an entire century, again marked by important milestones.

In the early decades after Italian Unification (1861), Sesto San Giovanni was essentially a farming village. Between 1860s and 1880s, the only manufacturing activities to develop were furniture making and silk production ${ }^{22}$. After the 1880s, however, a series of factors combined to transform the rural centre into what was shortly to become a "factory town"23. As will be explained below, Sesto's geographical position enabled it to

\footnotetext{
${ }^{20}$ For example, on the one hand the duration - and so the longevity - of the firm is calcaulated deducing the end date at the start date. On the other hand, the data on the ownership show the capacity of the firm to survive generational transition.

${ }^{21}$ For an accurate reconstruction of this process, see V. Zamagni, The economic history of Italy: 1860-1990, Oxford, Clarendon, 1993.

${ }^{22}$ The silk industry's role in Italian industrialisation is highlighted by V. Zamagni in The economic history of Italy, cit.

${ }^{23}$ In 1981, G. Petrillo compiled a book entitled La città delle fabbriche: Sesto San Giovanni 1880-1945 [The factory town]. Others after him used this expression to describe Sesto. For example, the 2002 volume published by the Milan Institute of Contemporary History proposes a "journey in $20^{\text {th }}$-century Sesto". More recently, in his 2009 book, D. Tavoliere refers to Sesto San Giovanni as the "Stalingrad of Italy", as well as the factory town.

For further details see: G. Petrillo (edited by), La città delle fabbriche: Sesto San Giovanni. 1880-1945, Sesto San Giovanni, Milan Institute of the History of the Resistance and the Labour Movement, CGIL, CISL, UIL Trade
} 
meet the industrial requirements of the time: on the one hand Italy's widespread production requirements, namely, facilities for mass production and skilled labour, and technological requirements, such as using electricity for production and extending outlet markets; on the other were requirements of a financial nature, as domestic and foreign capital was flowing into the area ${ }^{24}$. Following these four decades of settlement, the establishment of some of Italy's most important manufacturing plants at the time led, in the first decade of the $20^{\text {th }}$ century, to the confirmation of Sesto San Giovanni as an industrial town. As mentioned above, these plants were Società Italiana Ernesto Breda, Ercole Marelli and Acciaierie e Ferriere Lombarde Falck ${ }^{25}$.

Table 1. Italy' gross domestic product (GDP) between 1861 and 1988 (values calculated at constant prices)

\begin{tabular}{|c|c|c|}
\hline YEAR & $\begin{array}{c}\text { GDP INDEX } \\
(\mathbf{1 8 6 1} \mathbf{1 0 0})\end{array}$ & $\begin{array}{c}\text { AVERAGE ANNUAL GDP GROWTH } \\
\text { RATE }\end{array}$ \\
\hline 1861 & 100 & ---- \\
\hline 1896 & 131 & 0.8 \\
\hline 1913 & 198 & 2.4 \\
\hline 1922 & 231 & 1.7 \\
\hline 1929 & 271 & 2.2 \\
\hline 1938 & 315 & 1.6 \\
\hline 1951 & 359 & 1.0 \\
\hline 1963 & 719 & 5.8 \\
\hline 1973 & 1249 & 5.5 \\
\hline 1988 & 1965 & 3.1 \\
\hline
\end{tabular}

Source: V. Zamagni, The economic history of Italy, cit., p. 55.

Union Documentation Centre, 1981; A. Pizzi, La città delle fabbriche: viaggio nella Sesto S. Giovanni del '900, Milan Institute of Contemporary History, Cinisello Balsamo, 2002; D. Tavoliere, La chiamavano Stalingrado d'Italia. Sesto San Giovanni, la città delle fabbriche, Rome, LiberEtà, 2009.

${ }^{24}$ Cfr. C. Pavese, I caratteri originali dell'insediamento: un tentativo di analisi comparata, in L. Trezzi (edited by), Sesto San Giovanni 1880-1921. Economia e società: la trasformazione, Milan, Skira, p. 129.

${ }^{25}$ Other new production facilities sprang up in the wake of these major players. For example, Fratelli Santambrogio (building construction), Soc. Ing. Banfi (electricity supply), Corderie Metalliche Spadaccini and Pompe Gabbioneta were established in 1904. Laminatoio Nazionale, Acciaierie Elettriche and Fonderia Balconi were founded in Sesto two years later. Officine Camona and Fonderia Valsecchia Abramo merged the same year to become OSVA. Cfr. G. Oldrini, Il borgo agricolo, in E. Parma (edited by), Sesto San Giovanni. Storia, arte e cultura, Sesto San Giovanni, 1989, p. 181. 
The development of Sesto San Giovanni as an industrial town was derived mostly from the needs of the entrepreneurs of the time. Especially in the case of the great factories, industrialists were in search of suitable production sites where they could extend their activity, but without having to pay excessive costs. The great cities - Milan first and foremost - were no longer able to provide these conditions, so the choice of a suitable place for setting up or expanding production plants fell on Sesto San Giovanni. Another attraction for the industrialists was the fact that the town had a good availability of lowcost labour ${ }^{26}$. The town also offered plenty of land at reasonable prices and the advantage of a good geographical location. Sesto lies very close to Milan, the capital of Lombardy the country's most important business centre, and on a major communications network linking Milan and Europe, the St. Gotthard tunnel. Moreover, the town boasted good transport links with Milan and the rest of the region, an advantage for the numerous commuters ${ }^{27}$.

The production settlements established in the Sesto area operated in various fields of activity, ranging from food production ${ }^{28}$ to manufacturing. However, Sesto San Giovanni soon started to attract large-scale businesses dealing in metalworking, iron and steel production, electromechanical engineering, and, later, electrical engineering 29 .

Sesto San Giovanni was not merely a "town of [great] factories", however. The high concentration of production facilities in the area was also due to the large number of smaller firms set up there. This process of settlement dates back to the 1880s. Since its very beginning, therefore, the production system in Sesto San Giovanni simultaneously comprised large, medium, small and even "tiny" businesses ${ }^{30}$.

\footnotetext{
${ }^{26}$ At the company board meeting on 14 January 1903, Ernesto Breda highlighted the availability of labour as one of the main advantages of Sesto San Giovanni; cfr. Breda Archives, b. 4, file 1.

${ }^{27}$ C. Pavese, I caratteri originali dell'insediamento: un tentativo di analisi comparata, in L. Trezzi (edited by), Sesto San Giovanni 1880-1921, Economia e società: la trasformazione, Milan, Skira, 1997.

${ }^{28}$ Important firms in the food industry include Davide Campari, founded in 1902, and Maggi and Distillerie Maroni, both founded in 1908.

29 Ibid.

${ }^{30}$ The existence of a considerable number of small and medium enterprises was noted both in V. Varini, L'opera condivisa... L'industria, cit., and in I. Suffia, Un secolo di piccola e media impresa a Sesto San Giovanni: da fine Ottocento agli anni ottanta del Novecento, in L. Trezzi (edited by), Sesto San Giovanni alla fine del XX secolo. 1974-1996. L'eredità volta al futuro, Milan, Skira, 2012.

The co-existence of firms of varying size was not only true of Lombardy, however. In Turin, for example, a whole series of smaller factories developed around the FIAT; cfr. E. Borruso, Città e piccola industria: Milan (1881-1927), in F. Amatori and A. Colli (edited by), Comunità di imprese. Sistemi locali in Italia tra Ottocento e Novecento, Bologna, II Mulino, 2001. In the Canavese area, numerous small and medium production units were gradually built near the great Olivetti plant; cfr. R. Maglione, A. Michelsons and Sergio E. Rossi, Economie
} 
Most of the studies on Sesto's production have dwelt on the vicissitudes and the results of that limited core of large enterprises that made the town "great" in terms of production and economic growth. Local small and medium enterprises were usually relegated to the background. The result of this conception of the make-up of the production system was the creation of a certain cognitive gap between these two worlds. The literature shows, however, that the link between town and factory regardless of the size - was a long-term one that originated in the 1880s and continued for at least a 100 years. This observation reveals that business longevity can be considered a factor distinguishing the various businesses set up in Sesto San Giovanni during the $20^{\text {th }}$ century. In other words, the industrial town's at least century-long existence coincides with that of some of the firms operating there.

\section{Continuity and large enterprises in Sesto San Giovanni during the 1900s}

During the $20^{\text {th }}$ century, until the 1980 s, the continuity of the industrial system in Sesto San Giovanni was highlighted by the active presence of the great manufacturing plants. First, the perception of the lengthy existence of large enterprises, in the broad sense, manifested itself by the occupation of large areas of land. Vast portions of the town were set aside for building factories and all the infrastructures required in support of production activities. The various installations ranged from roads and residential buildings to entertainment facilities for the workers as well as the general community. Consequently, the "urban burden" of the industrial giants was borne directly by the community and the local political and cultural environment. For the local residents "the start and the end of the day, the passing of the months and the seasons [were] now marked [...] by the sound of [big business] sirens"31. The local authorities, on the other hand, had to focus their attention on the myriad factors that would allow Sesto first to become and later to assert itself as an industrial centre ${ }^{32}$. As mentioned above, these

\footnotetext{
locali tra grande e piccola impresa. Il caso di Ivrea e del Canavese, Fondazione Adriano Olivetti, Città di Castello (Perugia), 1990.

${ }^{31}$ Cfr. S. Licini, Operai a Sesto San Giovanni. Composizione e mobilità della forza lavoro alla Ercole Marelli (1929-1945), in Storia in Lombardia, 1987, p. 174.

32 In connection with the influence of Sesto San Giovanni's LEs on the general policy, it has been noted that "the activity of the large enterprises in Sesto allowed an appreciation [...] of the relevance and influence of public policies on their operations, revealing the use of the State in view of implementing the strategies pursued. State intervention, however, should be considered in its multiple formulations [...]", from the more invasive ones - such as "that which, in the case of Breda, led to the acquisition of ownership and associated management in an attempt to preserve the continuity of the company" - to "negotiated policies" - such as those "adopted in multiple formulations in favour of regulation of the competition, such as manufacturers'
} 
factors included such things as road and sanitary infrastructures, general healthcare, insurance and social security, and education, professional training and recreational facilities ${ }^{33}$. Second, the persistence of the great factories was confirmed by numerous scientific publications ${ }^{34}$, in addition to corporate publications. As regards companyproduced publications, Breda, for instance, celebrated its first 100 years of history most of which was spent in Sesto San Giovanni - with a jubilee issue in $1986^{35}$.

From the information gathered from research, historical documents and corporate publications, it has been possible to piece together a highly synthetic yet meaningful picture of the main features of the longevity of the large enterprises in Sesto. What follows applies to those enterprises operating in sectors qualified as specialist for Sesto $^{36}$. The temporal progression of the large production plants in Sesto took place in clearly identifiable stages. The start of the process coincided with the beginning of the $20^{\text {th }}$ century. The plants were established in the town between 1903 and 1910 and become some of the most important plants for the Italian economy at that time. This initial phase was followed by a period of rapid expansion due to the vast opportunities offered by the First World War. Post-war reconversion witnessed an initially difficult stage, followed by a further period of prosperity. This boost was the result of a new expansion associated with the Second World War. After post-war stagnation, with all the reorganisation problems that needed to be solved, came a time of more rapid industrial development - the boom of 1950s and 1960s. At the end of this positive cycle, the 1970s saw the start of an opposite trend, leading to the definite conclusion of the paradigm of the large enterprise ${ }^{37}$.

consortia", which were in force before the Great War and in the early 1930s - and to legislation on production activities; cfr. Varini, L'opera condivisa...L'industria, cit., p. 12.

${ }^{33}$ For further details of the role of Sesto San Giovanni town authorities in the first half of the $20^{\text {th }}$ century, see P. Tedeschi and L. Trezzi, L'opera condivisa. La città delle fabbriche. Sesto San Giovanni 1903-1952. La società, Milan, Franco Angeli, 2007.

${ }^{34}$ A systematic, accurate reconstruction of long-term events at Breda, Falck, Ercole Marelli and Magneti Marelli, is provided by V. Varini; cfr. V. Varini, L'opera condivisa...L'industria, cit. and V. Varini, La metamorfosi industriale: dalla città delle fabbriche all'impresa diffusa, in L. Trezzi (edited by), Sesto San Giovanni. 19531973. Economia e società: equilibrio e mutamento, Milan, Skira, 2007

${ }^{35}$ Cfr. AA.VV., La Breda. Dalla Società Italiana Ernesto Breda alla Finanziaria Ernesto Breda, Milan, A. Pizzi, 1986.

${ }^{36}$ The sectors involved are those see before: mechanical engineering, iron and steel production, electromechanical engineering and electrical engineering.

${ }^{37}$ In general, about the evolution of the italian enterprises see R. Giannetti, M. Vasta (edited by), Evolution of Italian Enterprises in the 20th Century, Physica-Verlag, New York, 2006.

A synthetic history on the Italians large enterprises is in F. Amatori, La grande impresa, in Storia d'Italia. L'industria. Imprenditori e imprese, vol. 22, Turin, Einaudi, 1999, pp. 732-756. Moreover, A. Carreras writes 
Having identified the periods that marked the existence of LEs in Sesto, all that remains is to summarise the main features that allowed the various firms to contribute, with more or less favourable economic trends, to over half a century of local history. In plain terms, it can be said that the elements determining the temporal success of Sesto's industrial giants were the combined result of public aid and managerial skills often concentrated in a restricted vertex of power ${ }^{38}$. The weight of each component clearly varied from case to case.

In Italy, the active role of the State as a "substitutive factor" in the consolidation of the country's modernisation process is well known ${ }^{39}$. "Premature State capitalism" actually led to the fact that "the first great deals [from the latter half of the 19 ${ }^{\text {th }}$ century in Savoy Piedmont to the early years following the Unification of Italy] originated from opportunities offered by State action"40. In Sesto, the State's propensity to create favourable opportunities for industrialisation applies, for instance, to the case of Breda. By seizing the opportunities offered by public contracts in the late $19^{\text {th }}$ century, the company succeeded over the next few years in achieving a "dimensional shift". The first upgrade occurred when the company became a corporation. Later growth was even more "physical", requiring new sites - found in Sesto San Giovanni - allowing future expansion ${ }^{41}$. Even so, the positive influence of the authorities cannot be considered the main factor determining the success of Sesto's LEs. The initiative of the entrepreneurs, "who were encouraged to operate according to the conveniences arising from the free combination of economic interests" 42 , was another key to the firms' success. Still focusing on Breda, it has been said that "of course, Breda's success was due not only to demand from the State [...]. Most important was the role of the entrepreneur, Ernesto Breda, who gave his name to the company in $1886[\ldots]$ [..43.

\footnotetext{
about general deindustrialisation in Italy in the last quarter of the $20^{\text {th }}$ century; cfr. A. Carreras, Un ritratto quantitativo dell'industria italiana, in Storia d'Italia. L'industria. I Problemi dello sviluppo economico, vol. 21, Turin, Einaudi, 1999, pp. 218-274.

${ }^{38}$ The centralisation of decision-making is a characteristic noted since the companies' early years in the importance attributed to their founders. Each included his own names in that of the company he founded: Ernesto Breda set up Società Italiana Ernesto Breda per Costruzioni Meccaniche and Ercole Marelli founded Ditta Ercole Marelli.

${ }^{39}$ Cfr. F. Amatori and A. Colli, Comunità di imprese, cit. p. 12. For further details see ibid.

40 lbid., p. 33.

${ }^{41}$ Ibid., pp. 52-53.

${ }^{42}$ Cfr. V. Varini, L'opera condivisa...L'industria, cit., p. 10.

${ }^{43}$ Cfr. F. Amatori, A. Colli, Comunità di imprese, cit., p. 53.
} 
The temporal persistence of the local industrial giants can therefore be considered a topic that has been discussed sufficiently in the literature and resolved. All that remains to be done is to determine the longevity of Sesto's SMEs as well.

\section{Small and medium enterprises in Sesto San Giovanni: a century of experience}

The industrial history of Sesto San Giovanni was characterised by "the existence of a considerable number of small and medium enterprises operating in the same sectors as the large ones [...]". Unfortunately, however, "the insufficient documentation available (for SMEs) makes it difficult to follow the stages of growth with accuracy and for some the reason for their eclipse" 44 , which is why numerous researchers have not dwelt on the world of SMEs in any depth. Nevertheless, an increased consideration of "minor" industry, in the economy at a national ${ }^{45}$ and local ${ }^{46}$ level, led to the need to investigate the longevity of this category of business more thoroughly. The prime objective, therefore, was to identify and reconstruct the system of SMEs in Sesto during the 20 century. The period of time taken into consideration stretches from their $19^{\text {th }}$ century origin to around the $1980 \mathrm{~s}$. The last two decades of the $20^{\text {th }}$ century witnessed a profound transformation of the industrial system in Sesto, when the rate of local industrialisation declined in favour of a sharp rise in the rate of tertiarisation ${ }^{47}$. The latter change, however, falls outside the scope of this study, so reference should be made to future investigations.

In the period considered, the industrial area in Sesto San Giovanni was, as we have observed, characterised by a high number of small and medium enterprises. The examination of the periodical sources - mentioned before - allowed approximately 450 firms of this size to be identified. The temporal distribution of this huge number of

\footnotetext{
${ }^{44}$ V. Varini, L'opera condivisa...L'industria, cit., p. 10.

${ }^{45}$ The general question of dimensional dualism is tackled in M.J. Piore and C.F. Sabel, The Second Industrial Divide: Possibilities for Prosperity, New York, Basic Books, 1984.

${ }^{46}$ In general, the "dimensional" situation of Italian industry is tackled in F. Traù, La questione dimensionale dell'industria italiana, Bologna, II Mulino, 1999. In the case of Italy, it has been stated that "small is beautiful"; cfr. Amatori and Colli, Impresa e industria in Italia dall'Unità ad Oggi, Venice, Marsilio, 1999, p. 315. Again as regards Italy, it has been shown that small enterprises formed the "basis of our economic development"; cfr. G. Becattini, Distretti industriali e made in Italy: le basi socioculturali del nostro sviluppo economico, Turin, 1998.

${ }^{47}$ For further details see: Ambiente e sviluppo della SME. Opportunità e limiti in alcune aree lombarde, Lombardy Regional Research Institute, Milan, Franco Angeli, 1987; L. Berti and C. Donegà, Sesto San Giovanni, gli scenari del cambiamento, Milan, Franco Angeli, 1992.
} 
production units provides an essential tool for determining whether the phenomenon of longevity can be associated with the number.

First, documents confirm that the origin of SMEs in Sesto San Giovanni dates back to the 19th century: "The first known metalworking factory opened in Sesto, somewhere between the late sixties and early seventies [of the $19^{\text {th }}$ century] [... $]^{\prime \prime} 4$. The actual process of establishing "non-farming" production activities in the town commenced in the 1880s: the "first, though very limited, increment in non-silk manufacturing" 49 occurred between 1887 and 1892. The metallurgical workshop belonging to "Pietro Erba for 'constructions in iron' [...] and the two belonging to Antonio Cattaneo [...] for the construction of dairy machinery and the manufacture of weights and measures"50 opened in the same years. In general, the entrepreneurial activities established in Sesto prior to the $20^{\text {th }}$ century were mainly artisanal, and were obviously small in size. It was in these few years that some of the previously established firms, such as the Castiglioni \& Recalcati and Andrea Marocco workshops, started showing signs of consolidation via an increase in the size of the workforce.

Nevertheless, the surge in industrial growth of SMEs did not come until the turn of the $20^{\text {th }}$ century51, when Pompe Gabbioneta (1897), Turrinelli \& C. (1898), Trafilerie e Corderie Metalliche Luigi Spadaccini (1901) and Camona Giussani \& C. (1901) were established. Unlike previously founded enterprises, these new ones focused mainly on productions designed to exploit the current technological innovations, namely, those using electricity for motors and the construction of metal vehicles ${ }^{52}$. Ultimately, with this technological transition, Sesto San Giovanni lost its connotation as a farming centre and increasingly took on that of an industrial town. Moreover, the importance of this primary industrial settlement resides essentially in having shown that the area possessed the necessary requisites, especially in terms of economic advantages, to promote the location of manufacturing activities ${ }^{53}$.

\footnotetext{
${ }^{48}$ G. Tonelli, Lo sviluppo del borgo agricolo, in L. Trezzi (edited by), Sesto San Giovanni 1880-1921. Economia e società: la trasformazione, Milan, Skira, p. 44.

49 Ibid., p. 54.

${ }^{50}$ Ibid.

${ }^{51}$ Note that for LEs the period of greatest urban migration was between 1903 and 1913, so a few years after SMEs.

${ }^{52}$ These technologies include motor cars, electric and other trolleys, accumulators, dynamo motors and transformers; Cfr. V. Varini, L'opera condivisa...L'industria, cit., p. 26.

${ }^{53}$ In general, the foundation of this initial core of workshops can be considered the "impulse" triggering the "endogenous and autonomous" process of development of local entrepreneurship; cfr. P.P. D'Attorre and V.
} 
The definitive turning point came in the first decade of the $20^{\text {th }}$ century. In 1910 , the number of production units eventually reached double figures: the Milan Guide quoted 12 manufacturing firms.

The trend in subsequent years with regard to the number of SMEs in the area is shown in Chart 1.

Chart 1. Number of SMEs in Sesto quoted in periodical publications (1910-1986).

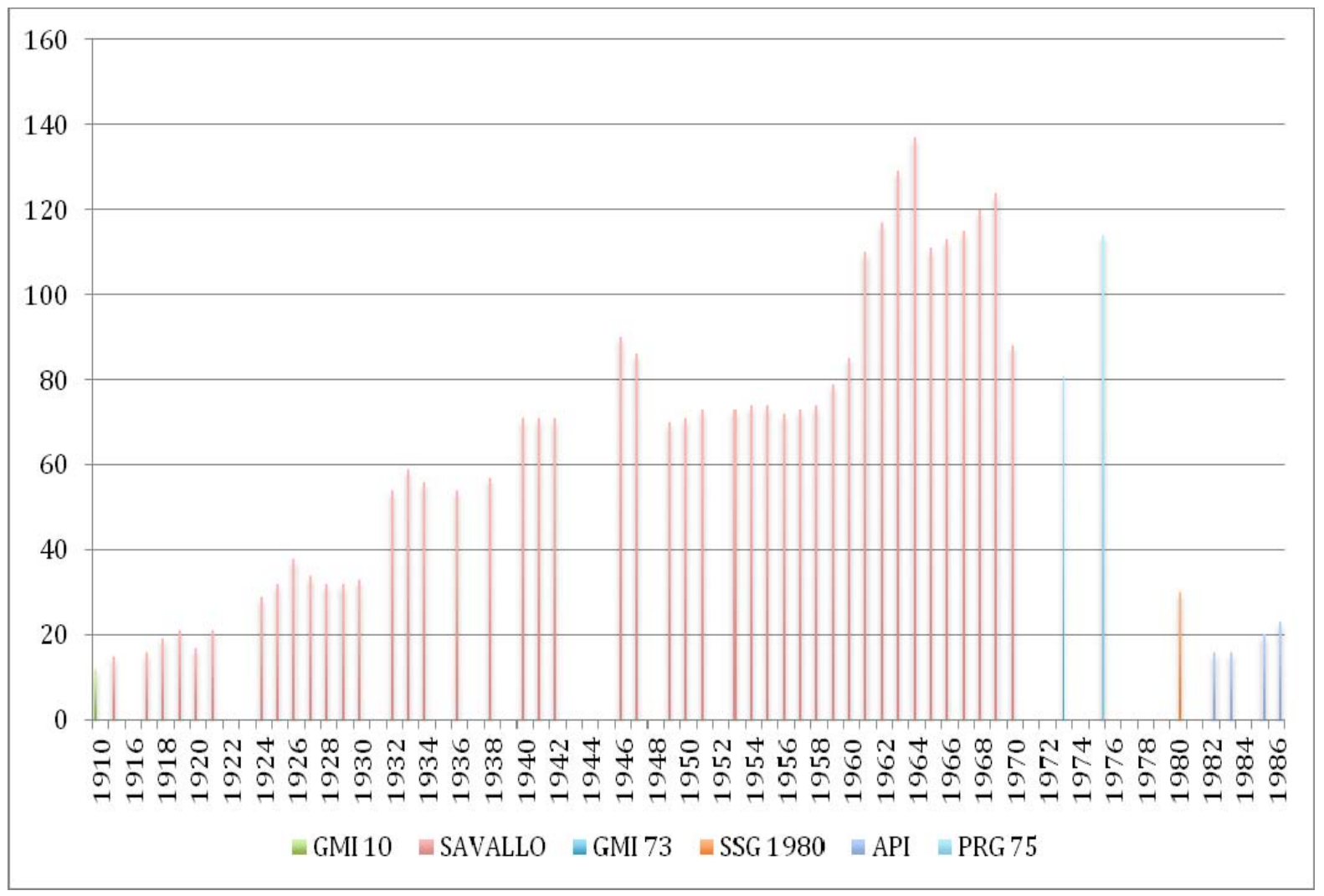

Source: personal analysis of figures from periodical sources.

Legend: GMI 10 = Milan Guide 1910, GMI 73 = Milan Guide 1973, SSG 1980 = Sesto San Giovanni: storia ed attività produttive, Settimo Milanese (Mi), Elegraf, 1980, API = series of API (Association of Small Firms) bulletins (1982-1986), PRG 75 = 1975 Urban Town Planning.

The overall trend highlights variable growth, especially in the 1970s, while the 1980s witnessed a sharp drop in the number of small and medium businesses operating in the area. As with local LEs, the periods of greatest strengthening of the system generally

Zamagni, Distretti, imprese, classe operaia: I'industrializzazione dell'Emilia Romagna, Milan, Franco Angeli, 1992, p. 50. 
coincided with positive cycles triggered by events affecting Italy's entire economic system. These periods are the first world war, the subsequent period of reconversion, the favourable economic policies of the 1930s, the early years of the second world war and the long economic boom of the 1950s and 1960s. The link between the highly varying number of SMEs in the local industrial scenario and the overall economic situation can be attributed to the non-linear growth of the average annual rate of the Italian GDP (Chart 2).

Chart 2. Average annual rate of growth in GDP, 1861-1988 (base $=1861$ )

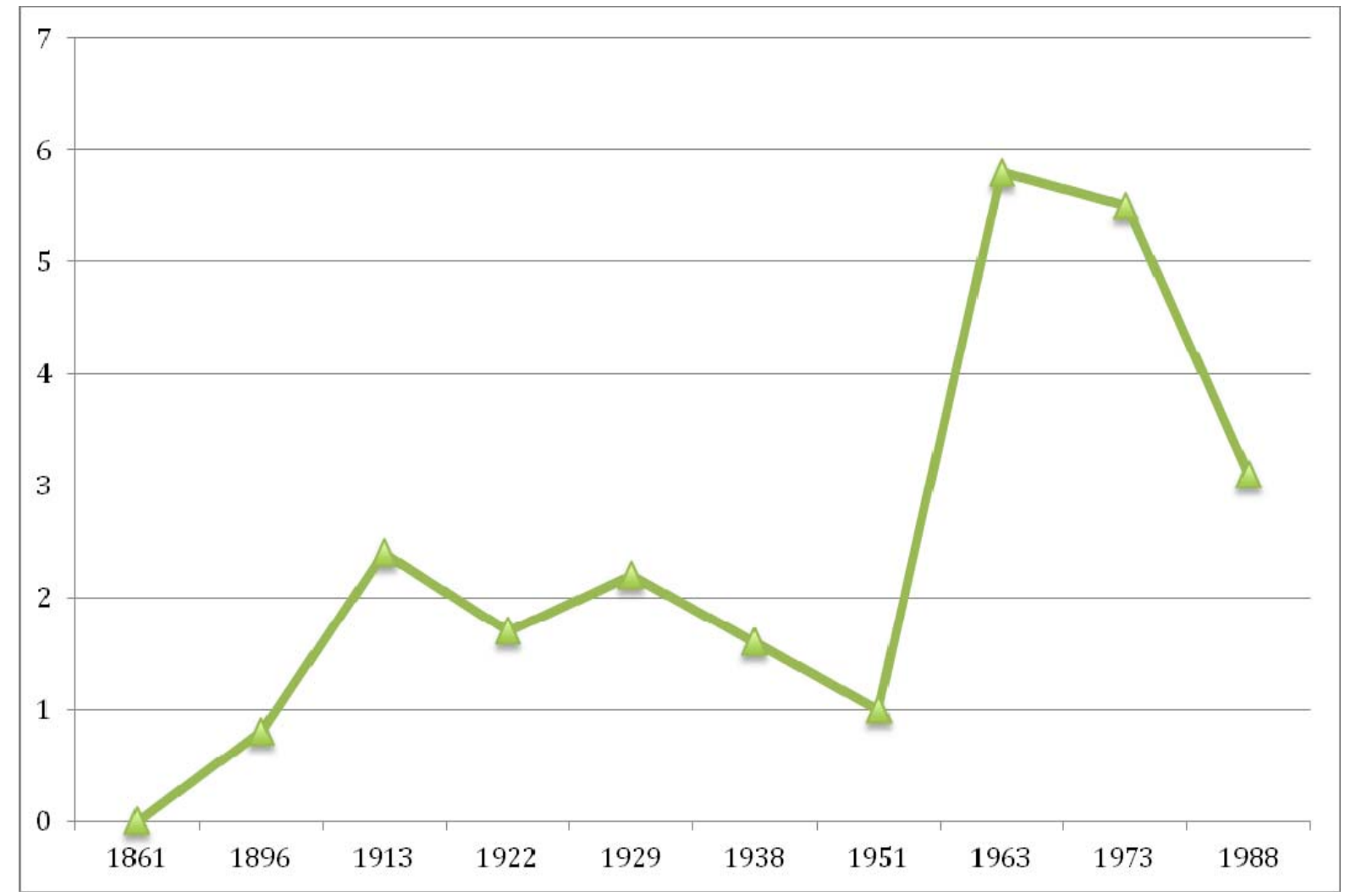

Source: figures taken from Table 1

It is clear that the declining number of SMEs from the early 1970s can be attributed to the general difficulty experienced by the Italian economy. This decline is also emphasised by the decline in the country's GDP between 1973 and 1988 . The sharp drop in production units in the 1980s can also be attributed to a general change in the approach of the SMEs themselves. There emerged the need for reinforcement in terms 
of quality and substance, rather than quantity ${ }^{54}$, as had occurred only until a short time earlier. Ultimately, therefore, with regard to the temporal presence of small and medium enterprises in Sesto San Giovanni, the most important fact highlighted by the analysis is the persistence of the system in the long term. Therefore, there was also the possibility that the longevity of the entire system could be transmitted to individual industrial realities.

\section{Longevity of small enterprises: fact or fiction?}

Periodical publications do not provide information on the longevity of each firm identified. Therefore, this study considered the firms' individual files held at the Chamber of Commerce in Milan to shows the temporal limits of enterprises ${ }^{55}$. The files include the various firms' statements of commencement and termination of activities, together with other declarations of a juridical and official nature. Unfortunately it was not possible to consult documents for all the SMEs presented in the list of names. The incompleteness of this source can be explained by numerous factors, first and foremost, their historical character, which often entails the loss of some the filed data.

Table 2. Distribution of "long-lived" firms by time classes (absolute values).

\begin{tabular}{|l|c|}
\hline Time bracket & No. of cases \\
\hline $30-40$ years & 28 \\
\hline $41-50$ years & 13 \\
\hline $51-60$ years & 7 \\
\hline $61-70$ years & 3 \\
\hline Over 70 years & 3 \\
\hline Total & $\mathbf{5 4}$ \\
\hline
\end{tabular}

Source: personal analysis of figures contained in the firms' files.

\footnotetext{
${ }^{54} \mathrm{M}$. Magatti found in general that "the eighties formed a watershed with respect to the long post-war period [...]". The same author pointed out that between 1990 and 1994 Lombardy enterprises suffered "a substantial halt in the self-expansion ability of entrepreneurial activity"; cfr. Magatti 1997, pp. 191-193.

For more about the substantial transformation of the system of SMEs in Sesto int the 1980s, see also V. Varini, p. 194.

${ }^{55}$ For more details about the limits and criticalities of the source, cfr. I. Suffia, Un secolo di piccola e media impresa, cit.
} 
The actual number of individual files it was possible to consult was 164 , and the following analysis is essentially based on these files ${ }^{56}$.

An examination of the duration of the various firms revealed that 54 of them existed for at least 30 years $^{57}$, and 13 of them for more than 70 (Table 2). The above figures clearly show that SMEs in Sesto San Giovanni were characterised by long-term existence. Longevity (30+ years) allplied to approximately $36 \%$ of the firms examined. This result is similar to that of the temporal existence of LEs in Sesto. The fact that the majority fall whitin the "30-40 years" and "41-50 years" classes shows that one of the factors determining the longevity of the companies was very likely generational transition. For these enterprises, such as the "family firms" referred to at the beginning, exceeding the "serious problem of generational change" 58 must be considered a determinant of continuity.

An analysis of the main features of SMEs in Sesto will identify the other components of longevity. The elements to be examined are the production sector, the legal form, and, hence, the ownership and management of the company ${ }^{59}$. Overall, the SMEs in Sesto that operated in the "characteristic" local business sectors ${ }^{60}$ displayed a strong preference for mechanical engineering61. This was reinforced by the fact that many SMEs chose to focus on certain specific areas, namely, metalworking and electromechanical engineering. As many as three-quarters of the small firms listed in the general directory opted for these sectors. The remaining quarter or so approximately $21 \%$ of the total - focused mainly on metallurgy. The bottom-ranking

\footnotetext{
${ }^{56}$ It should also be added that the number of firms undergoing subsequent analysis may differ due to a lack of information in the files. Restrictions may also be due to the lack of a statement of termination of activity. This applies for instance to Parmiani Amleto, founded in 1954, and Zanier Aldo, founded in 1938. Source: personal analysis of the firms' individual files.

${ }^{57}$ Note that length of existence was calculated as the difference between the years declared for commencement and termination of activity. There was generally no problem determining the year in which business commenced, but there were some discrepancies with regard to the year of termination, in which case reference was made to the year deemed to be accurate, namely the one declared. One case in point is that of Laminatoio Nazionale. The Chamber of Commerce was notified of termination of business when the liquidation report was filed on 15 December 1962, but the firm's own records show that it was wound up in June 1958. Therefore, in the few cases of temporal discrepancy, reference was made to the date on which actual termination was considered to have taken place. Source: personal analysis of the firm's individual file.

${ }^{58}$ Magatti, p. 194.

${ }^{59}$ Details of production activity engaged in were mainly obtained from various serial and quantitative sources. The documentation contained in the firms' individual files were consulted with regard to the other aspects. Source references are therefore provided in the text.

${ }^{60}$ For further details, see I. Suffia, Un secolo di piccola e media impresa, cit., p. 103.

${ }^{61}$ In this case the reference number was taken from periodical sources, therefore the total population was 407. Source: Ibid., p. 104.
} 
sectors were electrical engineering, with just over $2 \%$, and aeronautical engineering, with just one firm involved ${ }^{2}$. These figures clearly show that small businesses in Sesto displayed a strong propensity for metalworking and metallurgy. Unfortunately, from the data available, it was not possible to obtain further indications documenting the formation of a truly integrated group of firms, i.e., an industrial district. Nevertheless, a look at the general local conditions and the literature shows it is more plausible that the firms merely limited themselves to sharing the advantages of the location, and - except for a very limited number of cases - did not launch a more widespread joint project.

The second characteristic taken into consideration was the legal status declared by the firms at the start of their life. Chart 3 shows that SMEs of a "personal" nature prevailed ${ }^{63}$. By adding together the number of firms set up as one-man businesses and the number of those set up as partnerships, it can be observed that $80 \%$ of the new businesses opted for the "personal" category.

Chart 3. Legal status of SMEs in Sesto on the date of foundation in the $20^{\text {th }}$ century (\%)

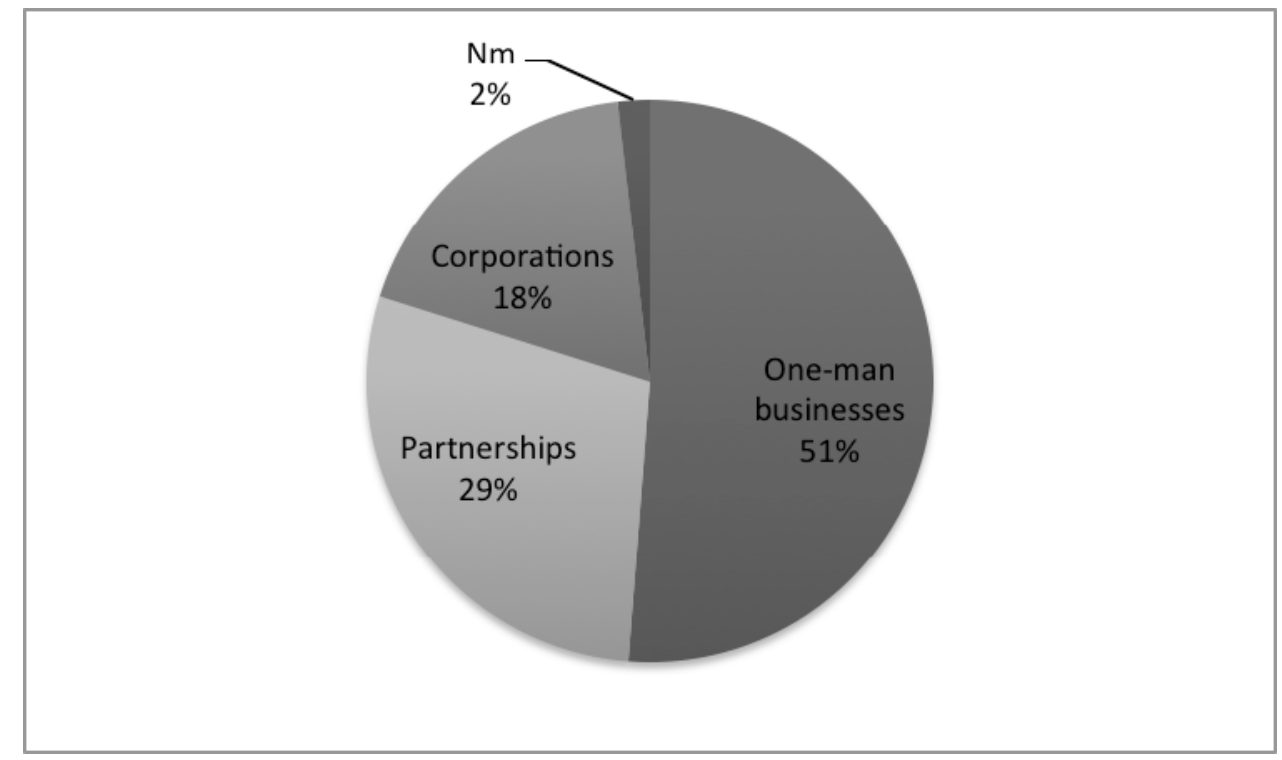

Source: personal analysis of data taken from company files.

Legend: $\mathrm{Nm}=$ not measured.

The legal status of a firm on the date of foundation is directly associated with ownership. Moreover, the clear predominance of one-man firms reflects a strictly

\footnotetext{
${ }^{62}$ Cfr. ibid., p. 104-105.

${ }^{63}$ Unlike previous considerations, the figures here were obtained from the firms' individual files. The total number of firms therefore dropped to 164. Source: ibid., p. 109.
} 
proprietary form of ownership. In short, it could be said that, in the case of Sesto San Giovanni, professional experience and direct human experience merged into one.

Table 3. Distribution of firms by type of administration (absolute and \% values)

\begin{tabular}{|l|c|c|}
\hline Type of administration & $\begin{array}{c}\text { Absolute } \\
\text { values }\end{array}$ & $\begin{array}{c}\text { Percentage } \\
\text { values }\end{array}$ \\
\hline SOLE DIRECTOR & 10 & 6.10 \\
\hline DIRECTORS & 4 & 2.44 \\
\hline BoD & 14 & 8.54 \\
\hline OWNER & 83 & 50.61 \\
\hline UNLIMITED LIABILITY PARTNERS & 4 & 2.44 \\
\hline EXECUTIVE DIRECTORS & 12 & 7.32 \\
\hline DFF & 27 & 16.46 \\
\hline UNLIMITED LIABILITY PARTNER & 2 & 1.22 \\
\hline EXECUTIVE DIRECTOR & 5 & 3.05 \\
\hline Nm & 3 & 1.83 \\
\hline Total & 164 & $\mathbf{1 0 0 . 0 0}$ \\
\hline
\end{tabular}

Source: personal analysis of data from the firms' individual files.

Legend: $\mathrm{BoD}$ = board of directors; $\mathrm{DFF}=$ de-facto firms; $\mathrm{Nm}$ = not measured.

The last "quality" aspect of SMEs in Sesto to be considered concerns the type of management. This relates, in turn, to the firm's legal status and type of ownership. The distribution by type of administration of the SMEs examined (Table 3) shows that business management and organisation were carried out by the owner in the case of one-man businesses and by the partners in the case of corporations. In the latter case, it also emerged that the partner or partners having direct ownership played a central role. In these SMEs, therefore, it is true to say that the "right" to run the business was proportional to the extent of ownership, i.e., to direct involvement in the company's interests.

The considerations made so far lead to the conclusion that the main determinants of $20^{\text {th }}$ century SMEs in Sesto San Giovanni are a certain specialisation in the metalworking 
sector and the personal contribution of the owner-manager. These are two of the factors determining the longevity of local small-scale businesses.

It should be added that the situation highlighted here essentially concerns the beginning of the life of the companies. The figures presented thus far are therefore of a static nature. Some of these characteristics have, opposite, changed and evolved over time. These changes have either involved the strengthening of a certain feature or a switch to different methods. In the latter case, the transformation may entail a different managerial approach, separating capital and family. With regard to production activity, Ciacci Cristoforo provides a good example of consolidation of existing skills. The company was established in 1928 and made "small metal parts - screws, nuts and bolts". It was decided later, in 1939, to add a "mechanical workshop for building various machines"64, evidence of a gradual shift towards the area's "strong" activities. As regards ownership, organisation and legal status, there are some examples where the factory retained close links with the founder, and others where new configurations were developed. An example of the continuing importance of the owner is Fratus Costruzioni Meccaniche, which switched from a de-facto firm to a general partnership in 1982. Another type of divergence in the personal character of the business took place in 1930, when FIGES (Fonderia Italiana Getti Speciali) changed from a general partnership to a stockholding company. There were also various episodes of convergence towards a "personal" character, as in the case of Fabbri \& Forni - Ciliotta Macchine Automatiche, which, after a period as a limited liability company was changed to a general partnership in 1954.

The above examples highlight a certain variability in the changes occurring in the qualitative features of each SME. For a better understanding of the dynamics and effects of the elements peculiar to small businesses, it is therefore necessary to analyse each type in greater detail based on the observation of individual cases. It will be then possible to determine whether, and how, the initial characteristics of SMEs were maintained in the long term, or whether they declined in intensity and consistency.

\footnotetext{
${ }^{64}$ Source: personal analysis of the firms' individual files.
} 


\section{Longevity of SMEs: some examples}

This chapter analyses the evolutionary stages of some of the SMEs established in Sesto in the $20^{\text {th }}$ century, with emphasis on industrial businesses that operated in the area for a long period of time.

The first example to consider is Elettromeccanica F. Arduini, which was set up on $1^{\text {st }}$ January 1945 and is still running, which means it has been in existence for nearly seven decades. In the company's own words, its main distinguishing features have always been its focus on "producing motors to drawing" and its ability to "solve customers' specific problems"65. The mainstays for the company's success "have always been dependability, quality and meeting the specifications or customers' requirements"66. Documents in the firm's own records reveal that a key element enabling the business to prosper for so long is the fact that the firm has always been owned and run by the same family67. In terms of business longevity, the case of Elettromeccanica F. Arduini is emblematic. It demonstrates that the combination of specialised production, supported by a customer and market-oriented policy, and family ownership and management are the principle reasons for the company's particular longevity.

The same successful blend of ownership and management by the same family can be observed with Ing. Gabbioneta, which was established in 1897. The Gabbioneta brothers, Luigi and Emilio, both engineers, sent a letter to the Milan Chamber of Commerce dated $15^{\text {th }}$ January 1907 giving notice of having "in communion a business of representation with a mechanical workshop in Sesto San Giovanni"68. Successive generations ran a business, and in 2001, the share capital was converted from lire to euros and divided equally between the heirs Gian Emilio, Giuseppe and Maria Maddalena ${ }^{69}$. It should also be noted that by continuing to specialise in one product category, in this case, pumps the company has achieved widespread international renown.

\footnotetext{
${ }^{65} \mathrm{Cfr}$. http://www.motoriarduini.com. The firm later extended its skills and now "boasts over 50 years' experience in the production of small electric motors and has specialised in the production of induction commutator, permanent magnet and suspension motors, cleaners, geared motors and sirens". It is a "leader in Italy in the areas of jewellery, dentistry equipment, coffee machines, office machinery and staplers". Source: ibid.

${ }^{66}$ Ibid.

${ }^{67}$ Source: personal analysis of the firm's files.

${ }^{68}$ The company was actually founded in Milan in 1897 and moved to Sesto San Giovanni in 1905, to a workshop "in the building owned by the Gabbioneta siblings, on provincial road to 12 to Monza". Source: personal analysis of the firm's files. ${ }^{69}$ Ibid.
} 
Another important family-run company operating in Sesto was founded by Biraghi Luigi on $15^{\text {th }}$ December 191970. The proprietor also had powers of signature and representation. In 1945, ownership was extended to include "his offspring Biraghi Giuseppe, Biraghi Remo and Biraghi Evelina”, and the one-man business became a defacto firm called "Costruzioni Meccaniche Luigi Biraghi e Figli"71. The founder left in 1957, after nearly half a century, and the company continued to be run by his offspring. The business was owned and managed by Giuseppe, Remo and Evelina into the new millennium ${ }^{72}$, but went into liquidation in 200573. Despite the outcome, this example shows how the elements of business longevity discussed herein favoured the persistence of the local industrial system for nearly a century.

Another significant industrial experience was that of Elettrotecnica Consonni. In 1929, Enrico Consonni founded his "factory for small-power electric motors", which employed two workers. A note-worthy fact is that the document reporting the establishment of the business submitted to the Milan Chamber of Commerce states that the "directing technical personnel" on the start-up date consisted of "the proprietor". Other documents in the archives reveal that ownership of the company remained in the Consonni family for various generations. The main generational transition occurred in 1942, when Beniamino Consonni, who had taken over from his father in the meantime, drew up an official notarial deed to "donate the workshop to my son Consonni Giuseppe". The reason for this legacy can be attributed to the donor's age, which "no longer allows me to adderess it [...]". On the date of transfer, the factory was in possession of three lathes worth 8,000 lire, one column drill worth 300 lire, one small drill worth 200 lire, one punch worth 500 lire and miscellaneous benches and equipment worth 1000 lire. Like both his predecessors, Giuseppe ran the business until he decided to retire from working life, in December 1980. The company closed down due to "withdrawal from business".

The above example conveniently introduces the last characteristic trait for understanding the determinants of the longevity of small businesses, namely, the ability to handle generational transitions successfully.

\footnotetext{
${ }^{70}$ In 1911 the company Biraghi Luigi took over the Biraghi \& Favetti workshop, which was located in Milan. Source: personal analysis of the firm's files.

71 Ibid.

${ }^{72}$ Remo Biraghi was later appointed chairman of the company. Source: ibid.

${ }^{73}$ See the decree issued by the Monza Court on $1^{\text {st }}$ March 2006, attesting the liquidation of the company following the approval of composition with creditors no. 4/2005. Source: ibid.
} 
In the absence of a "suitable" generational changeover to someone able to replace the owner efficiently, an SME was destined to disappear from the industrial scene. This means that another longevity factor - in addition to specialised production, centralised ownership and personal management - was the presence of internal entrepreneurial skills, or at least a direct interest in the business, allowing the company to keep going. Other cases confirm this. The case of the Troncon Umberto mechanical and repair workshop again shows that the owner's "withdrawal from business" led to the business being closed down. The firm was established for the "constructions of models for foundries" in January 1919 and shut down in August 1955, when the owner decided to retire $^{74}$. The one-man business Angusti Gino is a similar example. The "electric windings" factory commenced activity in 1949. Thirty-eight years later, the owner submitted to the Chamber of Commerce a compiled "Unified Termination Form" stating that the company had closed down due to his "withdrawal from business" on $24^{\text {th }}$ December 1987. Finally, the retirement of the last owner of Ditta Eredi di Mandelli Vittorio is the reason the factory ceased activity in July 1968. The firm had been founded by Vittorio Mandelli in 1933 to perform "shearing and tinsmith work". The first generational transition took place in 1949 on the death of the founder. The takeover was successful, and the one-man business became a de-facto firm owned by the founder's offspring ${ }^{75}$, thereby remaining in the family. A few years later, in 1959, two siblings withdrew from the company, which reverted to a one-man business owned by the remaining sibling, Giuseppe, who maintained the original name Ditta Eredi di Mandelli Vittorio. Giuseppe's "solo" venture only lasted a decade or so. He abandoned the industrial sector in July 196876.

The cases presented above confirm the results of the various surveys of the industrial system conducted previously. It has been shown that several factors - specialisation in metalworking, legal status, individual/personal ownership and management, and, lastly, "generational risk"- enabled SMEs in the Sesto area to operate throughout the $20^{\text {th }}$ century. These factors have been shown to interact systematically and be

\footnotetext{
${ }^{74}$ Source: personal analysis of the firm's files.

${ }^{75}$ Since two of the founder's three siblings were under age when he died, his mother and the eldest child, Giuseppe, continued to run the company until 1956. Later, when Giulio and Anna Mandelli came of age, they joined their brother, and their mother was excluded from the business. Source: personal analysis of the firm's files.

${ }^{76}$ Source: personal analysis of the firm's files.
} 
complementary to each other, yet they may have affected each production unit to a greater or lesser degree.

\section{Business longevity in Sesto: current scenario and prospects}

The theoretical and empirical analysis conducted in the course of this study led to two series of considerations. One final issue concerns the relationship between Sesto's entire economic system, i.e., for both LEs and SMEs, and the longevity factor. The other point concerns to the various components of SMEs' temporal persistence. Research into the relationship between the industrial system and firms' longevity has shown that the town's "industrial" vocation had a positive impact on temporal persistence.

In this area, an entrepreneurial "ecosystem" grew 77 , that led to the settlement of a particular local business system. This area does not have the features of the Italian industrial district because, in general, there was a low level of coordination and cooperation among enterprises ${ }^{78}$. Moreover, the area did not specialised in only one production chain. Nonetheless, positioning factors and logisticals elements contributed categorisation of Sesto San Giovanni as at "fragmented" business system 79 .

It is also important to consider that this natural "industrial atmosphere" was strengthened by state intervention intended principally to safeguard the industry. Although mainly focusing on protecting LEs, this intervention undoubtedly served to boost and develop smaller enterprises as well.

As regards the longevity elements concerning SMEs, it has been shown in the case of Sesto San Giovanni, as in other industrial areas, that the concentration of businesses in a specific sector was one reason for their temporal duration. Specialised local production can be interpreted as the means whereby the production units were able to exploit the opportunities offered by the "industrial atmosphere" in both tangible and intangible terms. From a tangible point of view, the concentration of specialised production is

\footnotetext{
${ }^{77}$ This means that in Sesto rose a kind of knowlegde oriented on the business. In the case of Silicon Valley the knowledge is even "in the air"; Martin Kenney (edited by), Understanding Silicon Valley, cit., p. xv.

${ }^{78}$ Joins among local industries was observed only in factories operating in the local steel and metal chain production; V. Varini, L'opera condivisa. La città delle fabbriche. Sesto San Giovanni 1903-1952. L'industria, Milan, Franco Angeli, 2006.

${ }^{79}$ The main charactheristic of this type are: relatively low levels of alliance integration (both degree and scope) and relatively low levels of authoritative coordination and control through ownership; Richard Whitley, Business Systems and Organizational Capabilities. The Institutional Structuring of Competitive Competeces, Oxford University Press, 2007, p. 13. For a synthesis about the "eight ideal types of business systems" see Ibid., pp. 13-17.
} 
clearly the result of the resources being available on site, or at least easy to procure. From an intangible point of view, perfection derives from the accumulation of knowledge and experience. In the Veneto region, reference has even been made to "knowledge and innovation [that] spread 'by cascade' [and] allow the transmission of know-how [up to the] creation of a specialised professional elite [...] and the [creation of] a widespread reserve of entrepreneurship encouraged [...] by the determination to succeed $[\ldots]^{\prime \prime} 80$.

The second longevity factor identified is the centrality of the personal element. For Sesto San Giovanni, the dominant role of the human factor has been demonstrated by the clear prevalence of firms with a single owner and an administrative-managerial control by the same person. Overall, a subject's "will to do", backed by an exceptional "ability to do", forms the basis of small-scale industrial systems elsewhere, such as the industrial district of Prato, which has been studied by M. Lungonelli81, and the Venetian districts in general, analysed by G. L. Fontana ${ }^{82}$.

The last factor influencing business longevity considered here is successful generational transition(s).

On the whole, if these transitions have a successful outcome, a certain longevity can be expected; if not, business persistence is reduced, although the extent varies from case to case. An analysis of the various businesses in Sesto has shown that the owner's retirement from business was usually the main reason for a company closing down. Cohesion between entrepreneur and enterprise, therefore, leads to the conclusion that the duration of the latter is dependent on the duration of the business commitment of the former. Problems due to generational transition have been highlighted in other studies, especially those covering family businesses, as noted earlier. This also applies to our study, because many SMEs are family-run businesses.

Currently, drawing together the threads of the discussion, it appears that the most important element for the longevity of the firms in Sesto is the 'human' factor. This is not a general human resource. Rather, it must be identified solely with the founder, or sometimes the founder members.

The findings and observations presented in this work provide an initial explanation of what determines business longevity in production systems consisting of small and

\footnotetext{
${ }^{80}$ Cfr. Fontana, in C. M. Belfanti, T. Maccabelli (edited by), Un paradigma per i distretti industriali, cit., p. 51.

${ }^{81} \mathrm{Cfr}$. M. Lungonelli, Sulle origini del distretto, cit.

${ }^{82}$ Cfr. G. L. Fontana, Radici storiche dei sistemi, cit.
} 
medium enterprises. Numerous questions remain unanswered, however, or at least require further analysis. In particular, considerable attention has been paid to the role of the entrepreneur and that of his family as a whole, but only limited research has focused on the characteristics of the entrepreneur and his entrepreneurial expectations. Another issue that has not yet received due attention is the relationship between business duration and technological innovation. A more in-depth analysis of these key elements in business longevity is therefore required. 


\section{BIBLIOGRAPHY}

AA.VV., La Breda. Dalla Società Italiana Ernesto Breda alla Finanziaria Ernesto Breda, Milan: A. Pizzi, 1986.

Amatori, Franco, and Colli Andrea, eds. Comunità di imprese. Sistemi locali in Italia tra Ottocento e Novecento, Bologna: Il Mulino, 2001.

Amatori, Franco, and Colli Andrea, Impresa e industria in Italia dall'Unità ad Oggi, Venice: Marsilio, 1999.

Amatori, Franco, and Jones Geoffrey, eds. Business History around the world, Cambridge: CUP, 2003.

Amatori, Franco, Colli Andrea, Business History. Complexities and comparaisons. London: Routledge, 2011.

Amatori, Franco, La grande impresa, in Storia d'Italia. L'industria. Imprenditori e imprese, vol. 22, Turin: Einaudi, 1999.

Ambiente e sviluppo della SME. Opportunità e limiti in alcune aree lombarde, Lombardy Regional Research Institute, Milan: Franco Angeli, 1987.

Bakr Ibrahim A., McGuire Jean and Soufani K., An Empirical Investigation of Factors Contributing to Longevity of Small Family Firms, in Global Economy \& Finance Journal, vol. 2, September 2009.

Becattini, Giacomo, Distretti industriali e made in Italy: le basi socioculturali del nostro sviluppo economico, Turin, 1998.

Becattini, Giacomo, ed., Economia della produzione. Milano: Isedi, 1975.

Berti, Lapo, and Donegà Claudio, Sesto San Giovanni, gli scenari del cambiamento, Milan: Franco Angeli, 1992.

Borruso Edoardo, Città e piccola industria: Milan (1881-1927), in F. Amatori and A. Colli (edited by), Comunità di imprese. Sistemi locali in Italia tra Ottocento e Novecento, Bologna, Il Mulino, 2001.

Carreras Albert, Un ritratto quantitativo dell'industria italiana, in Storia d'Italia. L'industria. I Problemi dello sviluppo economico, vol. 21, Turin, Einaudi, 1999.

Colli Andrea and Rose Mary, Family Business, in G. Jones and J. Zeitlin (edited by), The Oxford Handbook of Business History, Oxford, Oxford University Press, 2007.

Colli Andrea, Garcia-Canal Esteban and Guillén Mauro F., Family character and international entrepreneurship a historical comparison of Italian and Spanish 'new multinationals', in Business History Review, vol. 55, no. 1, January 2013. 
Corbetta, Guido, and Salvato Carlo, Strategies for Longevity in Family Firms: a European Perspective. London: Palgrave MacMillan, 2012.

D'Attorre, Pier Paolo, and Vera Zamagni, Distretti, imprese, classe operaia: l'industrializzazione dell'Emilia Romagna. Milan: Franco Angeli, 1992.

Fahed-Sreih Josiane, Djoundourian Salpie, Determinants of Longevity and Success in Lebanese Family Business. An exploratory Study, in Family Business Review, vol. 19, no. $3,2006$.

Fontana Gian Luigi, Radici storiche dei sistemi produttivi del Veneto, IN Terenzio Maccabelli (edited by), Un paradigma per i distretti industriali. Radici storiche, attualità e sfide future, Brescia, Grafo, 1997.

Foss Nicolai J., Understanding Business Systems: an Essay on the Economics and Sociology of Economic Organization, wp 97-6, Department of Industrial Economics and Strategy, Copenhagen Business School, 1997.

Garcia-Ruiz, José L., and Toninelli Pier Angelo, eds. The Determinants of Entrepreneurship, London: Pickering \& Chatto, 2010.

Giannetti, Renato, Michelangelo Vasta, eds. Evolution of Italian Enterprises in the 20th Century, New York: Physica-Verlag, 2006.

Jones, Geoffrey, and Zeitlin Jonathan, eds. The Oxford Handbook of Business History, Oxford: Oxford University Press, 2007.

Kenney, Martin (edited by), Understanding Silicon Valley. The anatomy of a Entrepreneurial Region, Stanford: Stanford University Press, 2010.

Licini Stefania, Operai a Sesto San Giovanni. Composizione e mobilità della forza lavoro alla Ercole Marelli (1929-1945), in Storia in Lombardia, 1987.

Lungonelli Michele, Sulle origini del distretto industriale pratese, in Carlo M. Belfanti and Terenzio Maccabelli (edited by), Un paradigma per i distretti industriali. Radici storiche, attualità e sfide future, Brescia, Grafo, 1997.

Maccabelli, Terenzio, ed. Un paradigma per i distretti industriali. Radici storiche, attualità e sfide future. Brescia: Grafo, 1997.

Maglione, Roberto, Michelsons Angelo, Rossi Sergio E., Economie locali tra grande e piccola impresa. Il caso di Ivrea e del Canavese, Città di Castello (Perugia): Fondazione Adriano Olivetti. 1990.

Oldrini Giuseppe, Il borgo agricolo, in E. Parma (edited by), Sesto San Giovanni. Storia, arte e cultura, Sesto San Giovanni, 1989.

Parma, Ezio, ed. Sesto San Giovanni. Storia, arte e cultura. Sesto San Giovanni: 1989. 
Pavese Claudio, I caratteri originali dell'insediamento: un tentativo di analisi comparata, in L. Trezzi (edited by), Sesto San Giovanni 1880-1921. Economia e società: la trasformazione, Milan, Skira, 1997.

Perricone Philippe J., Earle John R., Taplin Ian M., Patterns of Succession and Continuity in Family-Owned Business. Study of Ethnic Community, Family Business Review, vol. 14, no. 2, 2001.

Petrillo, Gianfranco, ed. La città delle fabbriche: Sesto San Giovanni. 1880-1945, Sesto San Giovanni: Milan Institute of the History of the Resistance and the Labour Movement, CGIL, CISL, UIL Trade Union Documentation Centre, 1981.

Piore, Michael J., and Sabel Charles F., The Second Industrial Divide: Possibilities for Prosperity. New York: Basic Books, 1984.

Signorini, Federico, ed. Lo sviluppo locale: un'indagine della Banca d'Italia sui distretti industriali. Corigliano Calabro: Mediana Libri, 2000.

Storia d'Italia. L'industria. I Problemi dello sviluppo economico, vol. 21, Turin: Einaudi, 1999.

Suffia Ilaria, Un secolo di piccola e media impresa a Sesto San Giovanni: da fine Ottocento agli anni ottanta del Novecento, in L. Trezzi (edited by), Sesto San Giovanni alla fine del XX secolo. 1974-1996. L'eredità volta al futuro, Milan, Skira, 2012.

Tavoliere, Damiano, La chiamavano Stalingrado d'Italia. Sesto San Giovanni, la città delle fabbriche. Rome: LiberEtà, 2009.

Tedeschi, Paolo, and Trezzi Luigi, L'opera condivisa. La città delle fabbriche. Sesto San Giovanni 1903-1952. La società. Milan: Franco Angeli, 2007.

Tonelli Giovanna, Lo sviluppo del borgo agricolo, in L. Trezzi (edited by), Sesto San Giovanni 1880-1921. Economia e società: la trasformazione, Milan, Skira, 1997.

Toninelli, Pier Angelo, Storia d'impresa, 2 ${ }^{\text {nd }}$ edition, Bologna: Il Mulino, 2012.

Traù, Fabrizio, La questione dimensionale dell'industria italiana. Bologna: Il Mulino, 1999.

Trezzi, Luigi, ed. Sesto San Giovanni 1880-1921. Economia e società: la trasformazione. Milan: Skira, 1997.

Trezzi, Luigi, ed. Sesto San Giovanni alla fine del XX secolo. 1974-1996. L'eredità volta al futuro, Milan: Skira, 2012.

Trezzi, Luigi, ed. Sesto San Giovanni. 1953-1973. Economia e società: equilibrio e mutamento. Milan: Skira, 2007. 
Trezzi, Luigi, Sesto San Giovanni. 1953-1973. Economia e società: equilibrio e mutamento. Milan: Skira, 2007.

Varini Valerio, La metamorfosi industriale: dalla città delle fabbriche all'impresa diffusa, in L. Trezzi, Sesto San Giovanni. 1953-1973. Economia e società: equilibrio e mutamento, Milano, Skira, 2007.

Varini Valerio, La metamorfosi industriale: dalla città delle fabbriche all'impresa diffusa, in L. Trezzi (edited by), Sesto San Giovanni. 1953-1973. Economia e società: equilibrio e mutamento, Milan, Skira, 2007.

Varini, Valerio, L'opera condivisa. La città delle fabbriche. Sesto San Giovanni 1903-1952. L'industria. Milan: Franco Angeli, 2006.

Whitley, Richard, Business Systems and Organizational Capabilities. The Institutional Structuring of Competitive Competeces, Oxford: Oxford University Press, 2007.

Whitley, Richard, Business Systems in East Asia, London: SAGE, 1992.

Whitley, Richard, European Business System. Firms and Markets in their National contexts. London: SAGE, 1992.

Zamagni, Vera, The economic history of Italy: 1860-1990. Oxford: Clarendon, 1993.

Zata Poutziouris, Panikkos, Smyrnios Kosmas X., Klein Sabine B., Handbook of Research on Family Business. Massachusetts: Edward Elgar Publishing, 2006.

Zelleweger Thomas Marcus, Nason Robert S., Nordqvist Mattias, From longevity to Transgenerational Entrepreneruship of Families. Introducing Family Entrepreneurial Orientation, in Family Business Review, vol. 25, no. 2, June 2012.

\section{ARCHIVES}

Breda Archives.

Municipal Archive of Sesto San Giovanni.

Milan Chamber of Commerce Historical Archive.

\section{OTHERS}

Api Milan: guida dell'associazione piccole e medie industrie di Milan e provincia, issues 1982-83 to 1986-1987.

Guida alle industrie della provincia di Milano, Milan, 1973.

Guida di Sesto San Giovanni Balsamo e Cinisello, Sesto San Giovanni, 1927.

Guida Industriale di Milano e Provincia, Milan, 1910.

Guida Savallo di Milano e provincia, Milan, issues 1915-1971 [lac.] 
Guida Ufficiale della Città di Sesto San Giovanni, Milan, 1936.

http://www.motoriarduini.com 